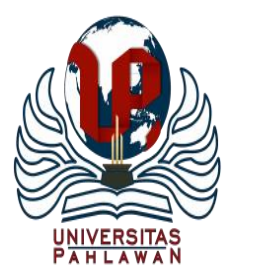

Edukatif : Jurnal Ilmu Pendidikan Volume 3 Nomor 5 Tahun 2021 Halm 2488 - 2500

EDUKATIF: JURNAL ILMU PENDIDIKAN

Research \& Learning in Education

https:/ledukatif.org/index.php/edukatif/index

\title{
Pengembangan Lembar Kerja Peserta Didik Berbasis Inkuiri untuk Meningkatkan Critical Thinking Peserta Didik di Sekolah Dasar
}

\author{
Selvia Yuniar ${ }^{1 凶}$, Arifin Maksum², Prayuningtyas Angger Wardhani ${ }^{3}$, \\ Medhitya Alda Apriliani ${ }^{4}$ \\ Pendidikan Guru Sekolah Dasar, Universitas Negeri Jakarta, Indonesia ${ }^{1,2,3,4}$ \\ E-mail : $\underline{\text { slvynr26@gmail.com }}{ }^{1}, \underline{\text { arifinmaksum@gmail.com }}^{2}$, prayuningtyasangger@gmail.com ${ }^{3}$, \\ mdhtya.alda@gmail.com ${ }^{4}$
}

\begin{abstract}
Abstrak
Permasalahan yang banyak ditemukan di sekolah dasar yaitu lembar kerja peserta didik (LKPD) yang digunakan dalam proses pembelajaran hanya berupa lembaran soal sehingga hanya menitikberatkan kemampuan verbalisme untuk memberikan jawaban tanpa mengetahui bagaimana mengkritisinya. Tujuan penelitian ini adalah mengembangkan dan mengetahui kelayakan pengembangan lembar kerja pesera didik (LKPD) berbasis inkuiri untuk meningkatkan critical thinking peserta didik kelas V SD. Penelitian ini adalah penelitian pengembangan $(\mathrm{RnD})$ yang mengadaptasi model pengembangan ADDIE yang terdiri dari lima tahapan yaitu analysis (analisis), design (desain), develpoment (pengembangan), implementation (implementasi) dan evaluation (evaluasi). Namun pada penelitian ini dilakukan hanya sampai dengan tahap development. Hasil validasi ahli materi, ahli bahasa, dan ahli media secara berurutan diperoleh skor $85 \%$, skor $65,33 \%$, dan skor 79\%. Berdasarkan hasil validasi LKPD secara keseluruhan diperoleh skor 76,44\% dengan kategori layak. Sehingga dapat dinyatakan LKPD berbasis inkuiri untuk meningkatkan critical thinking peserta didik kelas V sekolah dasar pada muatan IPA layak untuk digunakan.
\end{abstract}

Kata Kunci: LKPD, Inkuiri, Berpikir Kritis.

\begin{abstract}
The problem that is often found in elementary schools is that the student worksheets used in the learning process are only in the form of question sheets so that they only focus on verbalism skills to provide answers without knowing how to criticize them. The purpose of this study was to develop and determine the feasibility of developing inquiry-based student worksheets to improve the critical thinking of fifth grade elementary school students. This research is a development research that adapts the ADDIE development model which consists of five stages, namely analysis, design, development, implementation, and evaluation. However, in this research, only up to the development stage. The results of the validation of material experts, linguists, and media experts respectively obtained a score of $85 \%$, a score of $65.33 \%$, and a score of $79 \%$. Based on the results of the validation of student worksheets as a whole, a score of $76.44 \%$ was obtained with a decent category. So that it can be stated that the inquiry-based student worksheet to improve the critical thinking of grade V elementary school students on science content is feasible to use.
\end{abstract}

Keywords: Student Worksheet, Inquiry, Critical Thinking.

Copyright (c) 2021 Selvia Yuniar, Arifin Maksum, Prayuningtyas Angger Wardhani, Medhitya Alda Apriliani

$\triangle$ Corresponding author

Email :slvynr26@gmail.com

DOI : https://doi.org/10.31004/edukatif.v3i5.791

ISSN 2656-8063 (Media Cetak)

ISSN 2656-8071 (Media Online) 
2489 Pengembangan Lembar Kerja Peserta Didik Berbasis Inkuiri untuk Meningkatkan Critical Thinking Peserta Didik di Sekolah Dasar - Selvia Yuniar, Arifin Maksum, Prayuningtyas Angger Wardhani, Medhitya Alda Apriliani

DOI: https://doi.org/10.31004/edukatif.v3i5.791

\section{PENDAHULUAN}

Arus globalisasi pada abad 21 yang ditandai dengan pesatnya perkembangan ilmu pengetahuan dan teknologi telah mengubah berbagai sektor kehidupan. Untuk menghadapi perubahan global, sumber daya manusia (SDM) dituntut untuk memiliki keterampilan abad 21 atau biasa dikenal dengan 21 st Century Skills. 21st Century Skills terdiri dari keterampilan hidup dan berkarir, keterampilan belajar dan inovasi dan keterampilan teknologi dan media informasi (Wijaya et al., 2016). Untuk menguasai dapat ditempuh dengan jalur pendidikan. Dalam hal ini untuk mengefektifkan penguasaan keterampilan abad 21 perlu tiga elemen yang harus diterapkan bersama dalam pendidikan yaitu kurikulum, keahlian pendidikan, dan penilaian (Joyce $\&$ Calhoun, 2014).

Di Indonesia kurikulum yang diterapkan telah mengadaptasi keterampilan abad 21 yaitu kurikulum 2013 (K13) (Redhana, 2019). Hal itu bisa dilihat dari tujuan K13 yakni tercapainya kompetensi atau keterampilan agar peserta didik mampu menghadapi tantangan yang kompleks dimasa yang akan mendatang. Untuk itu peserta didik dituntut untuk menguasi 4 keterampilan yaitu berpikir kritis, komunikasi, kolaborasi, dan kreativitas (Mulyanto et al., 2020). Salah satu keterampilan yang perlu dikembangkan yaitu keterampilan berpikir kritis. Sejalan dengan itu pemerintah sendiri telah menetapkan kemampuan berpikir kritis sebagai salah satu tujuan pembelajaran pada kurikulum 2013 (Kemendikbud, 2017).

Kemampuan berpikir kritis merupakan kemampuan fundamental yang harus dimiliki peserta didik di abad 21. Berpikir kritis sendiri merupakan keterampilan yang mengedepankan kemampuan untuk memeriksa, menganalisis, menafsirkan, dan mengevaluasi bukti (Septikasari \& Frasandy, 2018). Harapannya melalui kemampuan berpikir kritis peserta didik mampu menggali, menemukan, dan menyelesaikan masalah secara mandiri serta mengambil keputusan secara kritis dan bertanggung jawab. Oleh karena itu kemampuan berpikir kritis harus dikembangkan sejak dini. Kemampuan berpikir kritis dapat dikembangkan melalui proses pembelajaran. Salah satunya melalui pembelajaran Ilmu Pengetahuan Alam (IPA).

Muatan pembelajaran IPA mempunyai peranan penting sebagai wadah untuk menumbuhkan, melatih, dan mengembangan kemampuan berpikir kritis pada peserta didik. IPA pada hakikatnya adalah suatu pembelajaran yang menekankan pendekatan ilmiah yang mengutamakan proses secara langsung dengan keterampilan proses sains seperti mengamati, klasifikasi, interprestasi, prediksi, hipotesis, melakukan eksperimen, mengendalikan dua variabel, dan mengkomunikasikan. Melalui pembelajaran IPA peserta didik dapat memperoleh pengalamannya langsung dan mengkonstruksi pengetahuan sendiri.

Akan tetapi, pada kenyataan di lapangan proses pembelajaran IPA yang dikembangkan oleh pendidik belum banyak melatih kemampuan berpikir kritis terbukti dari hasil Asesmen Kompetensi Siswa Indonesia (AKSI) tahun 2017 menunjukkan kemampuan rata-rata peserta didik adalah 37,11 dalam menalar yang mencakup kemampuan menganalisis informasi, menarik simpulan dan mengembangkan pemahaman sains (Puspendik dalam Budiono, 2020) Hal ini terjadi karena masih banyak tenaga pendidik yang menerapkan pembelajaran yang hanya mendorong peserta didik untuk berlomba mengalahkan teman sekelasnya. Sehingga dalam proses pembelajaran peserta didik hanya menitikberatkan pada kemampuan verbalisme untuk memberikan jawaban atas pertanyaan pendidik dengan cepat tanpa tahu bagaimana mengkritisinya (Sulistiyorini dalam Margunayasa et al., 2019). Pernyataan ini terbukti bahwa 4 dari 5 pendidik kelas V Sekolah Dasar di Wilayah Provinsi DKI Jakarta masih menggunakan model pembelajaran yang bersifat konteksual.

Untuk itu tenaga pendidik perlu mengubah pola pikir peserta didik dengan menerapkan model pembelajaran yang sebelumnya abstrak ke konteks dunia nyata. Salah satu model pembelajaran IPA untuk menumbuhkan keterampilan berpikir, bekerja dan bersikap ilmiah adalah inkuiri ilmiah (BSNP dalam Program et al., 2014). Pengajaran IPA lebih ditekankan pada pengajaran berbasis inkuiri yang proses 
2490 Pengembangan Lembar Kerja Peserta Didik Berbasis Inkuiri untuk Meningkatkan Critical Thinking Peserta Didik di Sekolah Dasar - Selvia Yuniar, Arifin Maksum, Prayuningtyas Angger Wardhani, Medhitya Alda Apriliani

DOI: https://doi.org/10.31004/edukatif.v3i5.791

pembelajarannya menuntut peserta didik berpikir lebih dalam dan kritis (Marshall \& Smart, 2013). Model pembelajaran inkuiri terdiri dari observasi, bertanya, mengajukan dugaan, pengumpulan data, sampai dengan proses menyimpulkan (Hermiyanty, Wandira Ayu Bertin, 2017).

Selain model pembelajaran, Lembar Kerja Peserta Didik (LKPD) juga merupakan bagian penting dalam proses pembelajaran. LKPD adalah lembaran yang berisi panduan dari pendidik kepada peserta didik untuk melakukan proses pembelajaran dalam bentuk kerja, praktik untuk mencapai suatu tujuan pembelajaran. LKPD yang baik akan mengembangkan pembentukan sikap, pengetahuan dan keterampilan (Hermiyanty, Wandira Ayu Bertin, 2017). Tetapi dalam penerapan disekolah-sekolah masih banyak LKPD yang dibuat kurang menarik yang di dalamnya hanya berisi soal tanpa mengacu pada kegiatan ilmiah. Hal itu didukung oleh temuan peneliti di Sekolah Dasar/Madrasah Ibtidaiyah di wilayah Provinsi DKI Jakarta bahwa 72,86\% peserta didik masih menggunakan LKPD yang hanya berisi soal-soal dan 58,93\% peserta didik menyatakan belum pernah melakukan kegiatan ilmiah dalam proses pembelajaran IPA. Untuk itu agar dapat mewujudkan pembelajaran yang menekankan kegiatan ilmiah yang mengarahkan peserta didik untuk mengembangkan proses berpikir kritis, LKPD dapat diintergrasikan berbasis inkuiri yang dikembangkan sendiri oleh pendidik.

Berdasarkan permasalahan yang telah dipaparkan di atas, penulis tertarik untuk mengembangkan LKPD berbasis inkuiri untuk meningkatkan critical thinking peserta didik kelas $\mathrm{V}$ sekolah dasar pada muatan ilmu pengetahuan alam (IPA) tema benda-benda di sekitar kita.

\section{METODE PENELITIAN}

Jenis penelitian ini merupakan penelitian pengembangan atau research and development (R\&D). Research and development (R\&D) merupakan metode penelitian yang tujuannya untuk menghasilkan produk dan menguji keefektifan produk agar dapat bermanfaat di masyarakat luas. Produk yang akan dikembangkan dalam penelitian ini ialah lembar kerja peserta didik (LKPD) berbasis inkuiri untuk meningkatkan critical thinking peserta didik kelas V sekolah dasar pada muatan ilmu pengetahuan alam (IPA) tema benda-benda di sekitar kita.

Metode pengumpulan data yang digunakan dalam penelitian dan pengembangan ini berupa angket berupa pertanyaan yang bersifat terbuka dan tertutup. Instrumen pengumpulan data berupa lembar analisis kebutuhan pendidik, lembar analisis kebutuhan peserta didik dan lembar uji validitas media, bahasa, dan materi. Subjek penelitian ini yaitu peserta didik kelas V di 4 Sekolah Dasar (SD) atau Madrasah Ibtidaiyah (MI) di wilayah provinsi DKI Jakarta, peserta didik kelas V di 4 Sekolah Dasar (SD) atau Madrasah Ibtidaiyah (MI) di wilayah provinsi DKI Jakarta, dan 3 validator.

Prosedur penelitian ini mengadaptasi model pengembangan ADDIE. Tahap-tahap ADDIE terdiri dari lima tahapan yaitu dari analysis (analisis), design (desain), develpoment (pengembangan), implementation (implementasi), dan evaluation (evaluasi). Namun pada penelitian ini dilakukan hanya sampai dengan tahap development.

Pada tahap analysis dilakukan untuk menganalisis masalah dasar yang dihadapi selama proses pembelajaran IPA di kelas dengan menganalisis kebutuhan, menganalisis kurikulum, dan menganalisis karakteristik peserta didik. Pada tahap design, dilakukan perancangan struktur LKPD, penyusunan dan pengumpulan objek rancangan, dan perancangan skenario pembelajaran dengan berbasis pembelajaran inkuiri. Pada tahap develpoment, dilakukan pembuatan LKPD berdasarkan rancangan dengan berbasis pembelajaran inkuiri dan melakukan uji validitas kelayakan LKPD aspek media, materi, dan bahasa oleh tim ahli pada lembar validasi ahli dengan kisi-kisi instrumen validasi sebagai berikut: 
2491 Pengembangan Lembar Kerja Peserta Didik Berbasis Inkuiri untuk Meningkatkan Critical Thinking Peserta Didik di Sekolah Dasar - Selvia Yuniar, Arifin Maksum, Prayuningtyas Angger Wardhani, Medhitya Alda Apriliani

DOI: https://doi.org/10.31004/edukatif.v3i5.791

Tabel 1. Kisi-Kisi Instrumen Validasi Materi

\begin{tabular}{lllc}
\hline \multicolumn{1}{c}{$\begin{array}{c}\text { Aspek Validasi } \\
\text { Materi }\end{array}$} & \multicolumn{1}{c}{ Indikator } & \multicolumn{1}{c}{$\begin{array}{c}\text { Nomor Butir } \\
\text { Penilaian }\end{array}$} & $\begin{array}{c}\text { Jumlah } \\
\text { Butir } \\
\text { Penilaian }\end{array}$ \\
\hline $\begin{array}{l}\text { Aspek Kelayakan } \\
\text { Isi/Materi }\end{array}$ & Kesesuaian Materi & $1,2,3,4$ & 4 \\
\cline { 2 - 4 } & Kedalaman Materi & 5,6 & 2 \\
\cline { 2 - 4 } & Keakuratan Materi & 7,8 & 2 \\
\cline { 2 - 4 } & Mendorong Untuk Berpikir Kritis & $9,10,11,12$ & 4 \\
\hline $\begin{array}{l}\text { Aspek Kelayakan } \\
\text { Penyajian }\end{array}$ & Teknik Penyajian Materi & 13,14 & 2 \\
\cline { 2 - 4 } & Pendukung Penyajian & $15,16,17,18$ & 2 \\
\cline { 2 - 4 } & Penyajian Pembelajaran & 19,20 & 20 \\
\hline Jumlah Butir & & & \\
\hline
\end{tabular}

Tabel 2. Kisi-Kisi Instrumen Validasi Bahasa

\begin{tabular}{|c|c|c|c|c|}
\hline \multicolumn{2}{|c|}{ Aspek Validasi Bahasa } & Indikator & $\begin{array}{l}\text { Nomor Butir } \\
\text { Penilaian }\end{array}$ & $\begin{array}{c}\text { Jumlah } \\
\text { Butir } \\
\text { Penilaian }\end{array}$ \\
\hline \multirow{2}{*}{\multicolumn{2}{|c|}{ Lugas }} & Ketepatan Struktur Kalimat & 1,2 & 2 \\
\hline & & Keefektifan Kalimat & 3,4 & 2 \\
\hline \multirow{2}{*}{\multicolumn{2}{|c|}{ Kaidah Bahasa }} & Ketepatan Tata Bahasa & $5,6,7,8,9$ & 5 \\
\hline & & Ketepatan Ejaan & $10,11,12,13$ & 4 \\
\hline \multirow{2}{*}{\multicolumn{2}{|c|}{$\begin{array}{l}\text { Kesesuaian dengan } \\
\text { Perkembangan Peserta } \\
\text { Didik }\end{array}$}} & $\begin{array}{l}\text { Kesesuaian dengan } \\
\text { Perkembangan Intelektual }\end{array}$ & 14 & 1 \\
\hline & & $\begin{array}{l}\text { Kesesuaian dengan } \\
\text { Perkembangan Emosional }\end{array}$ & 15 & 1 \\
\hline \multicolumn{5}{|c|}{ Tabel 3. Kisi-Kisi Instrumen Validasi Media } \\
\hline $\begin{array}{c}\text { Aspek } \\
\text { Validasi } \\
\text { Media }\end{array}$ & & Indikator & $\begin{array}{c}\text { Nomor } \\
\text { Butir } \\
\text { Penilaian }\end{array}$ & $\begin{array}{c}\text { Jumlah } \\
\text { Butir } \\
\text { Penilaian }\end{array}$ \\
\hline \multirow[t]{2}{*}{ Didaktik } & Proses & embelajaran & $1,2,3$ & 3 \\
\hline & Penger & bangan Kemampuan/ keterampilan & 4,5 & 2 \\
\hline \multirow[t]{3}{*}{ Konstruksi } & Memp & rhatikan Karakteristik Siwa & $6,7,8$ & 3 \\
\hline & Ketepa & an Penggunaan Bahasa sesuai EYD & 9 & 1 \\
\hline & Keleng & rapan & 10,11 & 2 \\
\hline \multirow[t]{3}{*}{ Teknis } & Penam & ilan & $12,13,14$ & 3 \\
\hline & Pengg & naan Tulisan yang Tepat & $15,16,17$ & 3 \\
\hline & Pengg & naan Ilustrasi/ Gambar yang Tepat & $18,19,20$ & 3 \\
\hline Jumlah & & & & 20 \\
\hline
\end{tabular}

Uji validitas yang dilakukan oleh validator mengacu pada pedoman pemberian skor berikut ini:

Tabel 4. Pedoman Pemberian Skor Uji Validitas

\begin{tabular}{cc}
\hline Nilai & Definisi \\
\hline $\mathbf{5}$ & Sangat baik \\
\hline $\mathbf{4}$ & Baik \\
\hline $\mathbf{3}$ & Cukup \\
\hline $\mathbf{2}$ & Kurang \\
\hline $\mathbf{1}$ & Sangat Kurang \\
\hline
\end{tabular}

Edukatif : Jurnal Ilmu Pendidikan Vol 3 No 5 Tahun 2021 p-ISSN 2656-8063 e-ISSN 2656-8071 
2492 Pengembangan Lembar Kerja Peserta Didik Berbasis Inkuiri untuk Meningkatkan Critical Thinking Peserta Didik di Sekolah Dasar - Selvia Yuniar, Arifin Maksum, Prayuningtyas Angger Wardhani, Medhitya Alda Apriliani

DOI: https://doi.org/10.31004/edukatif.v3i5.791

Data hasil perolehan uji validitas oleh validator dihitung dengan rumus berikut ini:

$$
\text { Skor Validitas LKPD }(\%)=\frac{\text { Jumlah skor total yang diperoleh }}{\text { Jumlah skor maksimal }} \times 100
$$

Hasil perolehan uji validitas LKPD, kemudian diinterpretasikan dan dikelompokkan ke dalam kategori (Arikunto dalam Prabandari \& Kristin, 2021) seperti pada Tabel 5. LKPD dinyatakan layak jika skor rata-rata $\geq 61 \%$.

Tabel 5. Kategori Kelayakan Produk

\begin{tabular}{cl}
\hline Interval & \multicolumn{1}{c}{ Kategori } \\
\hline $\mathbf{8 1 - 1 0 0 \%}$ & Sangat Layak \\
\hline $\mathbf{6 1 - \mathbf { 8 0 } \%}$ & Layak \\
\hline $\mathbf{4 1 - 6 0 \%}$ & Cukup Layak \\
\hline $\mathbf{2 1 - \mathbf { 4 0 \% }}$ & Tidak Layak \\
\hline$<\mathbf{2 1 \%}$ & Sangat Tidak Layak
\end{tabular}

\section{HASIL DAN PEMBAHASAN PENELITIAN}

Berdasarkan hasil penelitian mengenai pengembangan LKPD berbasis inkuiri untuk meningkatkan critical thinking peserta didik kelas $\mathrm{V}$ sekolah dasar pada muatan IPA materi zat tunggal dan campuran dengan mengadaptasi dengan model pengembangan ADDIE. Deskripsi data hasil penelitian dijelaskan sebagai berikut:

\section{Tahap Analysis (Analisis)}

Tahap analisis merupakan tahap dimana penulis mengetahui perlu tidaknya suatu pengembangan. Pada tahap ini peneliti melakukan analisis kebutuhan, menganalisis kurikulum, dan menganalisis karakteristik peserta didik.

Analisis kebutuhan dilakukan di 4 Sekolah Dasar (SD) yang berada di wilayah Provinsi DKI Jakarta dengan menyebar angket atau kusioner yang bersifat terbuka kepada pendidik kelas V SD secara online melalui google form. Berdasarkan penyebaran kusioner yang dilakukan maka didapatkan hasil sebagai berikut (1) pendidik masih mengalami kendala dalam proses pembelajaran IPA di kelas V yaitu kesulitan peserta didik dalam memahami materi belajar, kurang optimal dalam penerapan metode atau model pembelajaran yang sesuai dengan kurikulum 2013, dan ketersediaan media pembelajaran yang terbatas; (2) pendidik masih menggunakan model pembelajaran konvensional; (3) bahan ajar khususnya LKPD yang digunakan pendidik hanya berasal dari sekolah tidak mengembangkan sendiri; dan (4) LKPD yang digunakan dalam pembelajaran hanya berisi soal-soal, tidak bervariasi, dan tidak bergambar sehingga kurangnya ketertarikan oleh peserta didik. Dengan demikian, dibutuhkan LKPD berbasis model pembelajaran yang meningkatkan kemampuan berpikir kritis. Salah satu model pembelajaran yang berkaitan erat dengan berpikir kritis yakni model pembelajaran inkuiri (Budiono, 2020). Selanjutnya, dibutuhkan LKPD yang dikembangkan sendiri oleh pendidik dengan inovasi baru yang menarik yang tidak hanya berisi soal-soal.

Analisis karakteristik peserta didik dilakukan melalui penyebaran kuisioner kepada peserta didik kelas V sekolah dasar berjumlah 56 peserta didik. Berdasarkan hasil pengisian kusioner menunjukan bahwa 78,93\% 
2493 Pengembangan Lembar Kerja Peserta Didik Berbasis Inkuiri untuk Meningkatkan Critical Thinking Peserta Didik di Sekolah Dasar - Selvia Yuniar, Arifin Maksum, Prayuningtyas Angger Wardhani, Medhitya Alda Apriliani

DOI: https://doi.org/10.31004/edukatif.v3i5.791

peserta didik lebih senang melakukan percobaan atau proses menemukan dibandingkan hanya mendengar penyampaian materi metode cermah dari pendidik, $81,3 \%$ peserta didik menyukai LKPD yang bergambar dan $87,14 \%$ peserta didik membutuhkan LKPD khusus yang memuat materi zat tunggal dan zat campuran berbasis inkuiri (penemuan) yang di dalamnya terdapat percobaan agar memudahkan dalam memahami konsep dan mengembangkan keterampilan berpikir kritis. Dengan demikian dibutuhkan LKPD yang di dalamnya memuat lembar kegiatan percobaan/praktikum. Dengan adanya lembar kegiatan percobaan dapat memudahkan peserta didik dalam melakukan percobaan. Karena di dalamnya terdapat langkah-langkah yang harus dilakukan dalam percobaan sehingga proses pembelajaran dengan berinkuiri (menemukan) lebih terarah dan terstruktur (Pranaja \& Astuti, 2019).

Analisis kurikulum dilakukan dengan menganalisis SK dan KD dikhususkan pada materi zat tunggal dan campuran di kelas V tema 9 semester II. Selanjutnya menganalisis perangkat kurikulum yang berlaku yakni kurikulum 2013. Analasis ini menghasilkan rumusan indikator dan tujuan pembelajaran berdasarkan kompetensi inti dan kompetensi dasar yang sesuai dengan kurikulm 2013. Perumusan indikator pembelajaran berdasarkan kompetensi dasar sebagai berikut:

Tabel 6. Kompetensi Dasar dan Indikator Pembelajaran

\begin{tabular}{|c|c|}
\hline Kompetensi Dasar & Indikator Pembelajaran \\
\hline \multirow{2}{*}{$\begin{array}{l}3.9 \text { Mengelompokkan materi } \\
\text { dalam kehidupan sehari-hari } \\
\text { berdasarkan } \\
\text { penyusunnya (zat tunggal dan } \\
\text { campuran) }\end{array}$} & $\begin{array}{l}\text { 3.9.1 Mendiagnosis materi dalam kehidupan } \\
\text { sehari-hari berdasarkan komponen } \\
\text { penyusunnya (zat tunggal dan campuran) }\end{array}$ \\
\hline & $\begin{array}{l}\text { 3.9.2 Membuktikan perbedaan zat tunggal } \\
\text { dan campuran melalui percobaan }\end{array}$ \\
\hline $\begin{array}{lrr}4.9 & \text { Melaporkan } & \text { hasil } \\
\text { pengamatan } & \text { sifat-sifat }\end{array}$ & $\begin{array}{l}\text { 4.9.1 Melakukan percobaan mengenai zat } \\
\text { tunggal dan campuran }\end{array}$ \\
\hline $\begin{array}{l}\text { campuran dan komponen } \\
\text { penyusunnya dalam kehidupan } \\
\text { sehari-hari. }\end{array}$ & $\begin{array}{l}\text { 4.9.2 Menyajikan data hasil percobaan } \\
\text { mengenai sifat-sifat campuran dan komponen } \\
\text { penyusunnya dalam kehidupan sehari-hari }\end{array}$ \\
\hline
\end{tabular}

Berdasarkan indikator pembelajaran yang dirumuskan maka tujuan pembelajaran dirumuskan sebagai berikut : (1) peserta didik mampu merumuskan masalah mengenai zat tunggal dan zat campuran; (2) peserta didik mampu mengajukan hipotesis terhadap masalah yang telah dirumuskan tentang zat tunggal dan campuran; (3) peserta didik mampu merancang percobaan tentang zat tunggal dan campuran; (4) peserta didik dapat melakukan percobaan mengenai zat tunggal dan campuran; (5) peserta didik mampu menguji hipotesis mengenai zat tunggal dan campura; dan (6) peserta didik mampu menyimpulkan hasil berinkuiri (menemukan) mengenai zat tunggal dan campuran dengan tepat.

\section{Tahap Design (Desain)}

Tahap desain yaitu tahap perancangan LKPD yang akan dikembangkan dengan langkah-langkah sebagai berikut (1) penyusunan struktur LKPD. LKPD yang akan dikembangkan terdiri dari 3 bagian yaitu awal, isi, dan akhir. Berikut kerangka LKPD yang akan dikembangkan. 

Didik di Sekolah Dasar - Selvia Yuniar, Arifin Maksum, Prayuningtyas Angger Wardhani, Medhitya Alda Apriliani

DOI: https://doi.org/10.31004/edukatif.v3i5.791

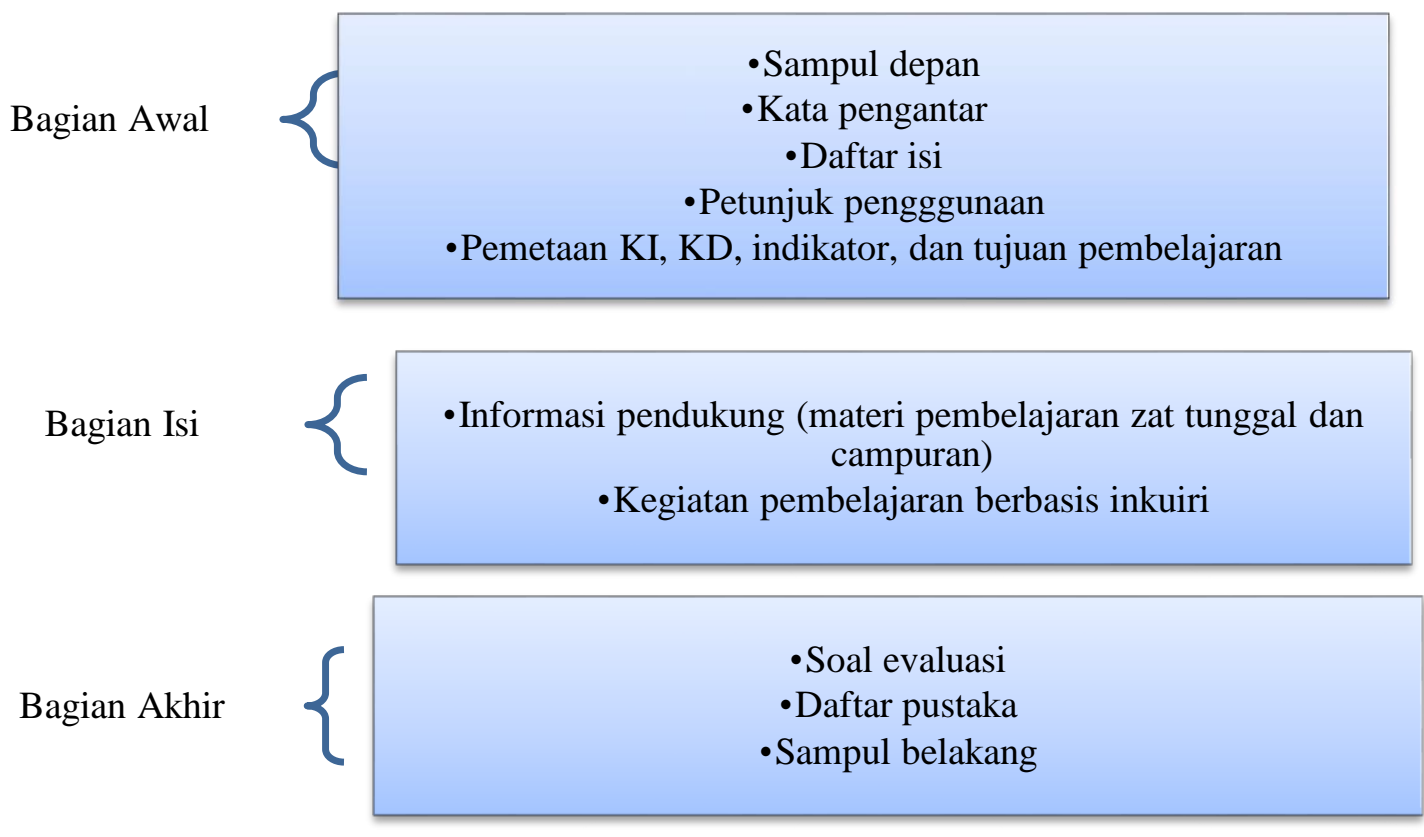

Gambar 1 : Kerangka LKPD

(2) penyusunan dan pengumpulan objek rancangan LKPD yaitu mengumpulkan materi pembelajaran dari berbagai referensi, pengumpulan gambar berupa gambar animasi maupun gambar hasil jepretan sendiri, dan menyusun soal latihan sebagai evaluasi pembelejaran; (3) perancangan skenario pembelajaran dengan berbasis pembelajaran inkuiri yang terdiri dari tahap orientasi masalah, merumuskan masalah, merumuskan hipotesis, pengumpulan data, menguji hipotesis, dan membuat kesimpulan; dan (4) penyusunan intrumen validasi ahli media, ahli materi, dan ahli bahasa.

\section{Tahap development (pengembangan)}

Pada tahap ini dilakukan pembuatan LKPD berdasarkan rancangan. Jadi dalam tahap pengembangan, struktur atau kerangka LKPD yang masih dirancang dan masih bersifat konseptual dapat direalisasikan menjadi produk LKPD yang berbasis inkuiri. Setelah itu, produk LKPD yang sudah dikembangkan harus melewati uji validasi oleh tim ahli yang terdiri dari ahli media, ahli materi dan ahli bahasa.

1) Hasil uji validitas oleh ahli materi pada produk, disajikan pada tabel berikut: 
2495 Pengembangan Lembar Kerja Peserta Didik Berbasis Inkuiri untuk Meningkatkan Critical Thinking Peserta Didik di Sekolah Dasar - Selvia Yuniar, Arifin Maksum, Prayuningtyas Angger Wardhani, Medhitya Alda Apriliani

DOI: https://doi.org/10.31004/edukatif.v3i5.791

\begin{tabular}{|c|c|c|c|c|c|c|}
\hline No & $\begin{array}{c}\text { Aspek Validasi } \\
\text { Materi }\end{array}$ & Indikator & $\begin{array}{c}\text { Jumlah } \\
\text { Butir } \\
\text { Penilaian }\end{array}$ & $\begin{array}{l}\text { Jumlah } \\
\text { Penilaian }\end{array}$ & $\begin{array}{c}\text { Jumlah } \\
\text { Penilaian } \\
\text { Maksimal }\end{array}$ & $\%$ \\
\hline \multirow[t]{4}{*}{1} & Aspek Kelayakan & Kesesuaian Materi & 4 & 19 & 20 & \multirow{8}{*}{$85 \%$} \\
\hline & Isi/Materi & Kedalaman Materi & 2 & 9 & 10 & \\
\hline & & Keakuratan Materi & 2 & 7 & 10 & \\
\hline & & $\begin{array}{l}\text { Mendorong Untuk } \\
\text { Berpikir Kritis }\end{array}$ & 4 & 17 & 20 & \\
\hline \multirow[t]{4}{*}{2} & $\begin{array}{l}\text { Aspek Kelayakan } \\
\text { Penyajian }\end{array}$ & $\begin{array}{l}\text { Teknik Penyajian } \\
\text { Materi }\end{array}$ & 2 & 7 & 10 & \\
\hline & & Pendukung Penyajian & 4 & 17 & 20 & \\
\hline & & $\begin{array}{l}\text { Penyajian } \\
\text { Pembelajaran }\end{array}$ & 2 & 9 & 10 & \\
\hline & \multicolumn{2}{|c|}{ Jumlah } & 20 & 85 & 100 & \\
\hline
\end{tabular}

Tabel 7. Hasil Uji Validitas Materi

Berdasarkan tabel di atas hasil uji validitas ahli materi yang mencakup 2 aspek yaitu: kelayakan isi/materi dan kelayakan penyajian diperoleh skor presentase kelayakan sebesar 85\%. Jika mengacu pada tabel 5 kriteria kelayakan produk, maka skor presentase diinterpretasikan dan dikelompokkan ke dalam kategori sangat layak. Adapun saran perbaikan yang diberikan oleh ahli materi yaitu background halaman seperti pada LKPD halaman 3, sebaiknya berwarna putih (jangan gelap) supaya gambar lebih jelas. Adapun hasil revisi LKPD berdasarkan saran perbaikan dari ahli materi dapat dilihat pada gambar 2 berikut:

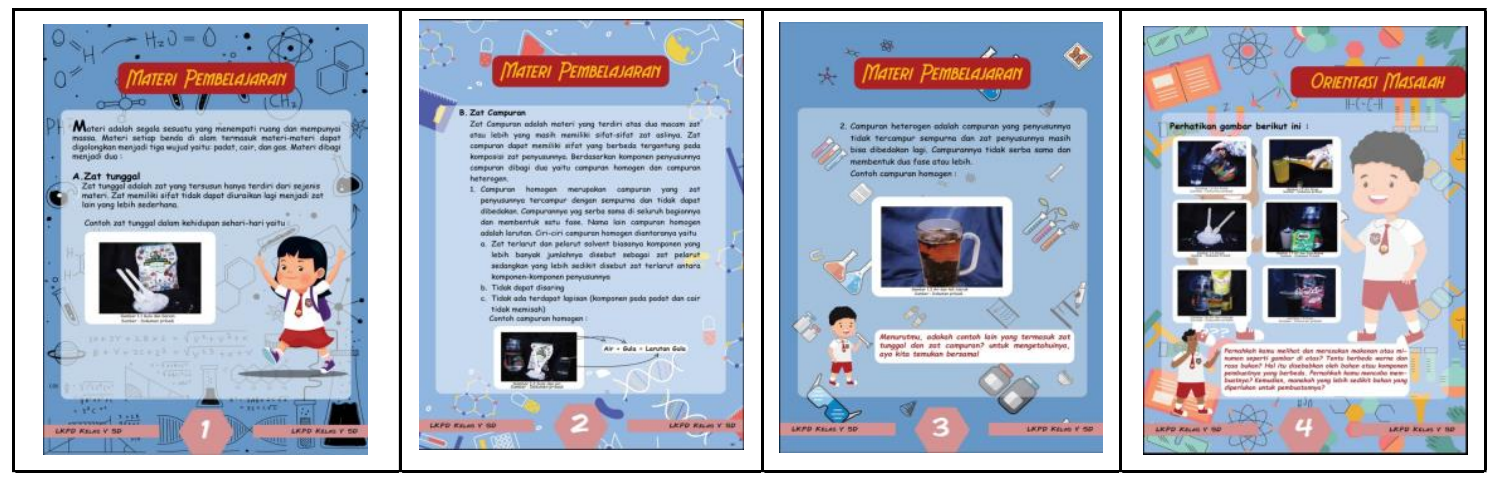

Gambar 2 : Hasil Revisi LKPD Kelayakan Materi

2) Hasil uji validitas oleh ahli bahasa pada produk, disajikan pada tabel berikut :

Tabel 8. Hasil Uji Validitas Bahasa

\begin{tabular}{|c|c|c|c|c|c|c|}
\hline No & $\begin{array}{c}\text { Aspek Validasi } \\
\text { Bahasa }\end{array}$ & Indikator & $\begin{array}{c}\text { Jumlah } \\
\text { Butir } \\
\text { Penilaian }\end{array}$ & $\begin{array}{l}\text { Jumlah } \\
\text { Penilaian }\end{array}$ & $\begin{array}{l}\text { Jumlah } \\
\text { Penilaian } \\
\text { Maksimal }\end{array}$ & $\%$ \\
\hline \multirow[t]{2}{*}{1} & \multirow[t]{2}{*}{ Lugas } & Ketepatan Struktur Kalimat & 2 & 7 & 10 & \multirow{5}{*}{$65,33 \%$} \\
\hline & & Keefektifan Kalimat & 2 & 8 & 10 & \\
\hline \multirow[t]{2}{*}{2} & Kaidah Bahasa & Ketepatan Tata Bahasa & 5 & 15 & 25 & \\
\hline & & Ketepatan Ejaan & 4 & 12 & 20 & \\
\hline 3 & $\begin{array}{l}\text { Kesesuaian } \\
\text { dengan }\end{array}$ & $\begin{array}{l}\text { Kesesuaian dengan } \\
\text { Perkembangan Intelektual }\end{array}$ & 1 & 4 & 5 & \\
\hline
\end{tabular}


2496 Pengembangan Lembar Kerja Peserta Didik Berbasis Inkuiri untuk Meningkatkan Critical Thinking Peserta Didik di Sekolah Dasar - Selvia Yuniar, Arifin Maksum, Prayuningtyas Angger Wardhani, Medhitya Alda Apriliani

DOI: https://doi.org/10.31004/edukatif.v3i5.791

\begin{tabular}{llccc}
\hline $\begin{array}{l}\text { Perkembangan } \\
\text { Peserta Didik }\end{array}$ & $\begin{array}{l}\text { Kesesuaian dengan } \\
\text { Perkembangan Emosional }\end{array}$ & 1 & 3 & 5 \\
\hline Jumlah & 15 & 49 & 75 \\
\hline
\end{tabular}

Berdasarkan tabel di atas hasil uji validitas ahli bahasa yang mencakup 3 aspek yaitu lugas, kaidah bahasa, dan kesesuaian dengan perkembangan peserta didik diperoleh skor presentase kelayakan sebesar 65,33\%. Jika mengacu pada tabel 5 kriteria kelayakan produk, maka skor presentase diinterpretasikan dan dikelompokkan ke dalam kategori layak.

3) Hasil uji validitas oleh ahli media pada produk, disajikan pada tabel berikut :

Tabel 9. Hasil Uji Validitas Media

\begin{tabular}{|c|c|c|c|c|c|c|}
\hline No & $\begin{array}{l}\text { Aspek } \\
\text { Validasi } \\
\text { Media }\end{array}$ & Indikator & $\begin{array}{c}\text { Jumlah } \\
\text { Butir } \\
\text { Penilaian }\end{array}$ & $\begin{array}{c}\text { Jumlah Skor } \\
\text { Total Yang } \\
\text { Diperoleh }\end{array}$ & $\begin{array}{c}\text { Jumlah } \\
\text { Skor } \\
\text { Maksimal }\end{array}$ & $\%$ \\
\hline \multirow[t]{2}{*}{1} & Didaktik & Proses Pembelajaran & 3 & 12 & 15 & \multirow{9}{*}{$79 \%$} \\
\hline & & $\begin{array}{l}\text { Pengembangan } \\
\text { Kemampuan/ keterampilan }\end{array}$ & 2 & 9 & 10 & \\
\hline \multirow[t]{3}{*}{2} & Konstruksi & $\begin{array}{l}\text { Memperhatikan } \\
\text { Karakteristik Siwa }\end{array}$ & 3 & 11 & 15 & \\
\hline & & $\begin{array}{l}\text { Ketepatan Penggunaan } \\
\text { Bahasa sesuai EYD }\end{array}$ & 1 & 4 & 5 & \\
\hline & & Kelengkapan & 2 & 10 & 10 & \\
\hline \multirow[t]{4}{*}{3} & Teknis & Penampilan & 3 & 11 & 15 & \\
\hline & & $\begin{array}{l}\text { Penggunaan Tulisan yang } \\
\text { Tepat }\end{array}$ & 3 & 11 & 15 & \\
\hline & & $\begin{array}{l}\text { Penggunaan Ilustrasi/ } \\
\text { Gambar yang Tepat }\end{array}$ & 3 & 11 & 15 & \\
\hline & & Jumlah & 20 & 79 & 100 & \\
\hline
\end{tabular}

Berdasarkan tabel di atas hasil uji validitas ahli media yang mencakup 3 aspek yaitu: didaktik, kontsruksi dan teknis diperoleh skor persentase kelayakan sebesar 79\%. Jika mengacu pada tabel 5 kriteria kelayakan produk, maka skor presentase diinterpretasikan dan dikelompokkan ke dalam kategori layak. Adapun hasil revisi LKPD sesuai dengan saran perbaikan yang diberikan oleh ahli media dapat dilihat pada gambar 3. 
2497 Pengembangan Lembar Kerja Peserta Didik Berbasis Inkuiri untuk Meningkatkan Critical Thinking Peserta Didik di Sekolah Dasar - Selvia Yuniar, Arifin Maksum, Prayuningtyas Angger Wardhani, Medhitya Alda Apriliani

DOI: https://doi.org/10.31004/edukatif.v3i5.791

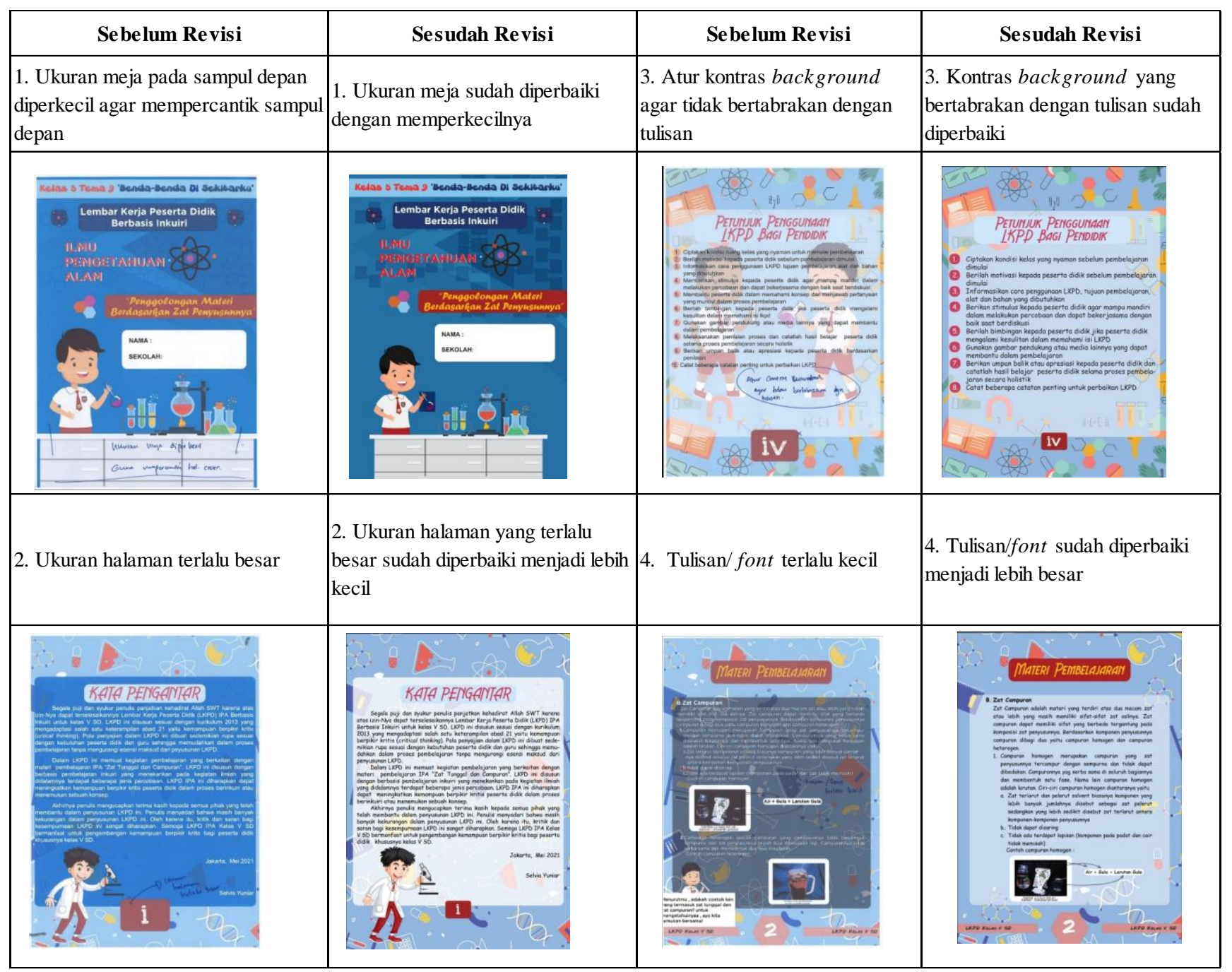

Gambar 3 : Hasil Revisi LKPD Kelayakan Media

\section{Pembahasan Penelitian}

Penelitian pengembangan ini menghasilkan bahan ajar berupa produk lembar kerja peserta didik (LKPD) berbasis inkuiri. Terdapat beberapa masalah yang melatarbelakangi pengembangan bahan ajar dalam penelitian ini diantaranya ialah bahan ajar yang digunakan pendidik di SD/MI masih berasal dari luar atau pihak penerbit sehingga hanya berisi soal-soal dan kurang menarik serta pendekatan atau model pembelajaran yang diterapkan oleh pendidik masih bersifat kovensional sehingga membuat peserta didik bosan dan kurang tertarik untuk mempelajari IPA dan menyebabkan peserta didik tidak menerima dan memahahmi konsep pembelajaran dengan baik. Padahal IPA merupakan salah satu pembelajaran yang penting karena diharapkan menjadi bekal untuk mengahadapi tantangan diabad 21 ini (Yuliati, 2017).

Menurut Nurdyansyah \& Fahyuni (2016) proses pembelajaran yang efektif untuk mengembangkan potensi peserta didik terjadi bukan hanya dari inisiatif peserta didik secara individu melainkan peserta didik memerlukan peranan guru dan sumber belajar. Sumber belajar yang dimanfaatkan pendidik dalam pembelajaran yaitu bahan ajar. Bahan ajar merupakan salah satu komponen pembelajaran yang penting sebagai pedoman dalam mengarahkan peserta didik untuk mencapai suatu kompetensi atau keterampilan (Magdalena et al., 2020). Salah satu bahan ajar yang dapat memudahkan pendidik dan peserta didik dalam melakukan proses pembelajaran adalah lembar kerja peserta didik (LKPD). LKPD merupakan bahan ajar yang memudahkan peserta didik untuk menemukan konsep pembelajaran karena di dalamnya terdapat lembaran 
2498 Pengembangan Lembar Kerja Peserta Didik Berbasis Inkuiri untuk Meningkatkan Critical Thinking Peserta Didik di Sekolah Dasar - Selvia Yuniar, Arifin Maksum, Prayuningtyas Angger Wardhani, Medhitya Alda Apriliani

DOI: https://doi.org/10.31004/edukatif.v3i5.791

petunjuk pelaksanaan pembelajaran sehingga menuntut peserta didik untuk berpikir dalam menyelesaikan tugas sesuai dengan indikator yang hendak dicapai (Firdaus \& Wilujeng, 2018). Untuk menghubungkan dan mengatur pola interaksi tiga komponen utama belajar yakni bahan ajar, pendidik, dan peserta didik maka diperlukan model pembelajaran. Pendekatan pokok dalam K-13 yang sesaui dengan kebutuhan abad 21 yaitu pembelajaran inkuiri (Diah Rusmala Dewi, 2019). Dengan adanya LKPD yang terintegeritas dengan pembelajaran inkuiri, peserta didik akan lebih aktif dan kritis karena dilibatkan secara langsung untuk mencari dan menemukan sendiri sebuah konsep pembelajaran.

LKPD IPA yang dikembangkan bukan hanya menyajikan soal-soal tetapi juga menyajikan kegiatan pembelajaran yang mengacu pada langkah-langkah sitematis berinkuiri yaitu orientasi, perumusan masalah, pengajuan hipotesis, pengumpulan data melalui eksprimen, menguji hipotesis, dan memberikan sebuah kesimpulan. Langkah-langkah tersebut sangat erat kaitannya dengan elemen kecapakan berpikir kritis yakni interpretasi, analisis, inferensi, dan eksplanasi. Sehingga pembelajaran inkuiri dapat meningkatkan berpikir kritis dari segi kognitif maupun disposisi afektif (Rositawati, 2019). LKPD IPA berbasis inkuiri ini dapat menjelaskan materi zat tunggal dan zat campuran yang sifatnya abstrak menjadi konkret melalui kegiatan bereksperimen atau praktikum sederhana. Hal tersebut sesuai dengan karakteristik peserta didik V SD yang usianya bekisar 7-11 tahun menurut teori kognitif Piaget berada padatahap operasional konkret yang berarti anak lebih senang terlibat secara langsung dalam kegiatan atau proses pembelajaran (Bujuri, 2018).

Suatu poduk dikatakan layak digunakan jika sesuai dengan kriteria yang telah ditetapkan. Kriteria yang digunakan dalam penilaian perangkat pembelajaran yaitu kevalidan, kepraktisan, dan keefektifan suatu produk. Produk dikatakan valid jika merujuk pada penilaian ahli, produk dikatakan praktis harus dinilai dari dua dimensi yaitu peniaian pengguna dan penilaian ahli, dan produk dikatakan efektif apabila produk memberikan dampak sesuai dengan yang telah ditetapkan (Parta, 2017). Dengan demikian, berdasarkan hasil penelitian di atas produk LKPD berbasis inkuiri untuk meningkatkan critical thinking peserta didik kelas $\mathrm{V}$ SD/MI disimpulkan bahwa produk yang dikembangkan hanya layak secara validitas namun belum diketahui kepraktisan dan keefektifannya. Namun berdasarkan hasil penelitian terdahulu yang serupa yang telah diuji cobakan kepada subjek penelitian membuktikan dan memperlihatkan hasil yang positif terhadap kepratisan dan keefektifan produk LKPD berbasis inkuiri. Penelitian sebelumnya yang dilakukan oleh Oktariayani, dkk. (2020) telah menghasilkan LKPD berbasis inkuiri terhadap kemampuan berpikir krtitis peserta didik kelas IV SD/MI dinyatakan layak secara validitas sebesar 83 dengan kategori sangat valid, kepraktisan produk sebesar 88,5 dengan kategori sangat praktis dan keefektifan sebesar 87,77 dengan kategori sangat efektif. Selain itu penelitian sejenis juga sudah dilakukan oleh Risky, dkk. (2018) menghasilkan LKPD berbasis inkuiri yang dinyatakan efektif dengan skor uji coba perorangan sebesar 98,73\%, uji coba kelompok kecil sebesar 98,39\%, dan uji coba lapangan sebesar $93,71 \%$.

\section{KESIMPULAN}

Penggunaan model inkuiri dengan variasi menggunakan LKPD yang menarik dapat memberikan pengalaman baru bagi peserta didik dalam kegiatan pembelajaran, sehingga peserta didik menjadi antusias, aktif, kritis, dan lebih memahami konsep pembelajaran. Hal tersebut sesuai dengan hasil penelitian bahwa kelayakan produk lembar kerja peserta didik (LKPD) berbasis inkuiri yang dikembangkan dan diberikan penilaian oleh validator secara keseluruhan memperoleh hasil presentase sebesar 79\% dengan kategori layak, sehingga pengembangan LKPD berbasis inkuiri untuk meningkatkan critical thinking peserta didik kelas 5 sekolah dasar pada muatan IPA dari aspek media, bahasa, dan materi dinyatakan valid dan layak digunakan dalam proses pembelajaran. 
2499 Pengembangan Lembar Kerja Peserta Didik Berbasis Inkuiri untuk Meningkatkan Critical Thinking Peserta Didik di Sekolah Dasar - Selvia Yuniar, Arifin Maksum, Prayuningtyas Angger Wardhani, Medhitya Alda Apriliani

DOI: https://doi.org/10.31004/edukatif.v3i5.791

\section{UCAPAN TERIMA KASIH}

Terima kasih kepada Program Studi Pendidikan Guru Sekolah Dasar Universitas Negeri Jakarta yang telah memberikan kesempatan peneliti untuk meneliti dan mengembangkan bahan ajar berupa LKPD, validator yang sudah memberikan penilaian validasi, dan semua pihak yang telah berkontribusi dalam penelitian ini sehingga penelitian berjalan dengan baik dan lancar.

\section{DAFTAR PUSTAKA}

Budiono, J. D. (2014). Bioedu Bioedu. 3(3), 571-579.

Bujuri, D. A. (2018). Analisis Perkembangan Kognitif Anak Usia Dasar Dan Implikasinya Dalam Kegiatan Belajar Mengajar. Literasi (Jurnal Ilmu Pendidikan), $\quad 9(1), \quad 37$. Https://Doi.Org/10.21927/Literasi.2018.9(1).37-50

Diah Rusmala Dewi. (2019). Pengembangan Kurikulum Di Indonesia Dalam Menghadapi Tuntutan Abad Ke21. As-Salam: Jurnal Studi Hukum Islam \& Pendidikan, 8(1), 1-22. Https://Doi.Org/10.51226/Assalam.V8i1.123

Firdaus, M., \& Wilujeng, I. (2018). Pengembangan LKPD Inkuiri Terbimbing Untuk Meningkatkan Keterampilan Berpikir Kritis Dan Hasil Belajar Peserta Didik Developing Students Worksheet On Guided Inquiry To Improve Critical Thinking Skills And Learning Outcomes Of Students. Jurnal Inovasi Pendidikan IPA, 4(1), 26-40. Http://Journal.Uny.Ac.Id/Index.Php/Jipi

Hermiyanty, Wandira Ayu Bertin, D. S. (2017). Pendekatan Konsep Dan Pendekatan Lingkungan. In Journal Of Chemical Information And Modeling (Vol. 8, Issue 9).

Joyce, B., \& Calhoun, E. (2014). The 21st-Century Skills. Realizing The Promise Of 21st-Century Education: An Owner's Manual, 46-66. Https://Doi.Org/10.4135/9781483387451.N6

Kemendikbud. (2017). Panduan Implementasi Kecakapan Abad 21 Kurikulum 2013 Di SMA. Kementerian Pendidikan Dan Kebudayaan, I-45.

Magdalena, I., Sundari, T., Nurkamilah, S., Nasrullah, \& Amalia, D. A. (2020). Analisis Bahan Ajar. Nusantara: Jurnal Pendidikan Dan Ilmu Sosial, 2(2), 311-326. Https://Ejournal.Stitpn.Ac.Id/Index.Php/Nusantara

Margunayasa, I. G., Dantes, N., Marhaeni, A. A. I. N., \& Suastra, I. W. (2019). The Effect Of Guided Inquiry Learning And Cognitive Style On Science Learning Achievement. International Journal Ofmargunayasa, I. G., Dantes, N., Marhaeni, A. A. I. N., \& Suastra, I. W. (2019). The Effect Of Guided Inquiry Learning And Cognitive Style On Science Learning Achievement. International Journal Of Instruction, 12(1), 737-750. Https:, 12(1), 737-750. Https://Doi.Org/10.29333//ji.2019.12147a

Marshall, J. C., \& Smart, J. B. (2013). Teachers' Transformation To Inquiry-Based Instructional Practice. Creative Education, 04(02), 132-142. Https://Doi.Org/10.4236/Ce.2013.42019

Mulyanto, B. S., Sadono, T., Koeswanti, H. D., Dasar, S., Wonodoyo, N., Tengah, J., Kristen, U., Wacana, S., \& Tengah, J. (2020). Evaluation Of Critical Thinking Ability With Discovery Lerning Using Blended Learning Approach In Primary School. 9(2).

Nurdyansyah, \& Fahyuni, E. F. (2016). Inovasi Model. In Nizmania Learning Center.

Oktariayani, O., Roza, M., \& Remiswal, R. (2020). Pengembangan Lembar Kerja Peserta Didik Berbasis Inkuiri Terbimbing Terhadap Kemampuan Berfikir Kritis Peserta Didik Kelas IV SD/MI. Jurnal Tarbiyah Al-Walad, 10(2), 123-132.

Parta, I. N. (2017). Model Pembelajaran Inkuiri. Buku Departemen Matematika Universiitas Negeri Malang, $I, 138-139$. 
2500 Pengembangan Lembar Kerja Peserta Didik Berbasis Inkuiri untuk Meningkatkan Critical Thinking Peserta Didik di Sekolah Dasar - Selvia Yuniar, Arifin Maksum, Prayuningtyas Angger Wardhani, Medhitya Alda Apriliani

DOI: https://doi.org/10.31004/edukatif.v3i5.791

Prabandari, A. S., \& Kristin, F. (2021). Pengembangan LKS IPS Berbasis Creative Problem Solving Untuk Meningkatkan Kemampuan Berpikir Kreatif Siswa Di Sekolah Dasar. Edukatif: Jurnal Ilmu Pendidikan, 3(2), 355-363. Https://Doi.Org/10.31004/Edukatif.V3i2.309

Pranaja, A., \& Astuti, Y. (2019). Edukatif: Jurnal Ilmu Pendidikan. Jurnal Ilmu Pendidikan, 1(3), 294-302. Https://Edukatif.Org/Index.Php/Edukatif/Index

Program, J., Universitas, P., Ganesha, P., Studi, P., \& Dasar, P. (2014). E-Journal Program Pascasarjana Universitas Pendidikan Ganesha Program Studi Pendidikan Dasar (Volume 3 Tahun 2013). Sage Journal, 3(1), 1-11. Https://Www.Academia.Edu/4879643/

Redhana, I. W. (2019). Mengembangkan Keterampilan Abad Ke-21 Dalam Pembelajaran Kimia. Jurnal Inovasi Pendidikan Kimia, 13(1).

Risky, M., Anak Agung, G. A., \& Komang, S. I. (2018). Pengembangan LKS Berbasis Inkuiri Terbimbing Mata Pelajaran IPA Di SD Negeri 4 Kampung Baru. Jurnal Edutech Universitas Pendidikan Ganesha, 9(2), 246-256.

Rositawati, D. N. (2019). Kajian Berpikir Kritis Pada Metode Inkuiri. Prosiding SNFA (Seminar Nasional Fisika Dan Aplikasinya), 3, 74. Https://Doi.Org/10.20961/Prosidingsnfa.V3i0.28514

Septikasari, R., \& Frasandy, R. N. (2018). Keterampilan 4C Abad 21 Dalam Pembelajaran Pendidikan Dasar. Tarbiyah Al-Awlad, VIII(2), 112-122.

Wijaya, E. Y., Sudjimat, D. A., \& Nyoto, A. (2016). Transformasi Pendidikan Abad 21 Sebagai Tuntutan. Jurnal Pendidikan, 1, 263-278. Http://Repository.Unikama.Ac.Id/840/32/263-278 Transformasi Pendidikan Abad 21 Sebagai Tuntutan Pengembangan Sumber Daya Manusia Di Era Global .Pdf. Diakses Pada; Hari/Tgl; Sabtu, 3 November 2018. Jam; 00:26, Wib.

Yuliati, Y. (2017). Literasi Sains Dalam Pembelajaran Ipa. Jurnal Cakrawala Pendas, 3(2), 21-28. Https://Doi.Org/10.31949/Jcp.V3i2.592 